\title{
A Comparative Study of Selected Motor Fitness Component Between Soccer Players And B.P.Ed Students
}

\author{
Sumanta Majhi ${ }^{1}$, Samir Hazra ${ }^{2}$, Sujit Singh ${ }^{3}$ \\ ${ }^{1}$ [Assistant Professor, Department of Physical Education, (B.P.Ed), Garhbeta College, West Bengal, India] \\ ${ }^{2}$ [Assistant Professor, Department of Physical Education, (B.P.Ed), Garhbeta College, West Bengal, India] \\ ${ }^{3}$ [Research Scholar, West Bengal State University, West Bengal, India]
}

\begin{abstract}
The purpose of the present study was to compare the selected motor fitness component between the Soccer Players and B.P.Ed Students. For this 15 male Soccer Players from Vidyasagar University, West Bengal and 15 Male B.P.Ed students from Vidyasagar University, West Bengal age between 19 - 25 years, were selected as subjects for the study. Thus the total no. of subjects for the present study were thirty $(N=30)$. The variables chosen for the study were Speed, Agility and Explosive Leg Strength variables are tested by using 50 $y d s$ run, $4 \times 10 y d s$ shuttle run and standing broad jump respectively. ' $t$ ' test was applied to investigate the existing of significant difference of the variables between soccer players and B.P.Ed students. The result of the study showed that there was a significant difference in Speed, Agility and Explosive Leg Strength between soccer players and B.P.Ed students.
\end{abstract}

Key word: Speed, Agility and Explosive Leg Strength.

\section{Introduction}

Worldwide 1960s to now the explosion of fitness awareness throughout the world ushers in the burgeoning fitness industry, with an onslaught of fitness information, scientific studies, celebrity exercise systems, products and services on a scale never seen before, giving the impression that modern civilized humans are committed to healthy bodies.Physical fitness is a general state of health and well-being and, more specifically, the ability to perform aspects of sports or occupations. Physical fitness is generally achieved through correct nutrition, exercise, hygiene and rest. It is a set of attributes or characteristics seen in people and which relate to the ability to perform a given set of physical activities.

Soccer is one of the most widely played sports in the world and is a sport characterized by short sprints, rapid acceleration or deceleration, turning, jumping, kicking, and tackling. It is generally assumed that through the years, the game has developed to become faster, with more intensity and aggressive play than seen previously. Elite soccer is a complex sport, and performance depends on a number of factors, such as physical fitness, psychological factors, player technique, and team tactics.

Schools, College that provide physical education from an early age have understood the importance of all round growth. Physical education helps in development of muscles and bones and children kept fit from an early age. Obesity is a problem among many children and this can be partly solved by stressing on physical education. Obesity can lead to many problems such as diabetes, heart problems and imbalances in hormones in children. Encouraging physical education in schools will help to contain the problem of obesity to an extent. Children who are enrolled in some form of sport or the other reap the benefits in the long run.

Some Students show signs of interest in sports from an early age and these prodigies should be encouraged and given the proper amount of guidance in schools. In India several Students are restricted from playing sports, despite showing signs of early excellence. With proper support and systems in place children will be able to bring out the best in themselves and they may even go on to represent the country at some point in the future. Thus, encouraging physical education India is important and schools must realize the potential benefits that can be achieved from just a few hours of activity every day. Thus, the investigator wants to differentiate the motor fitness between soccer players and B.P.Ed students

\section{Statement Of The Problem}

The purpose of the study was to compare and investigate the selected motor fitness components between the Soccer Players and B.P.Ed. Students.

\section{Methodology}

For the purpose of the study 15 male University Soccer Players and 15 Male B.P.Ed students from Vidyasagar University, West Bengal and age range $19-25$ years was selected randomly as subjects for this study. To compare the Speed, Agility and Explosive Leg Strength the following test are considered. 
1. For speed, the students were asked to run as fast as they can up to 50 yards and the result were recorded to the nearest $1 / 10^{\text {th }}$ seconds

2. $4 \times 10 y d s$ Shuttle Run Test were administered to measure agility and the results were recorded to the nearest $1 / 10^{\text {th }}$ seconds

3. Standing Broad Jump was administered to measure explosive leg strength and the results were recorded in feet and inches.

To compute all the results Students ' $t$ ' test was employed at 0.05 level of significance.

\section{Finding}

Table -1: Mean Standard deviation and ' $t$ ' test in Speed, Agility, Explosive leg strength, between Soccer

Players and B.P.Ed. students.

\begin{tabular}{|l|l|l|l|l|l|}
\hline \multirow{2}{*}{ Variables } & \multicolumn{2}{|l|}{ Soccer Players } & \multicolumn{2}{l|}{ B.P.Ed. Students } & \multirow{2}{*}{ T Ratio } \\
\cline { 2 - 5 } & Mean & SD & Mean & SD & \\
\hline Speed & 7.18 & .36 & 6.51 & .31 & $4.47^{*}$ \\
\hline Agility & 10.26 & .31 & 9.66 & .22 & $4.61^{*}$ \\
\hline Explosive Leg Strength & 2.49 & .07 & 2.30 & .08 & $4.75^{*}$ \\
\hline
\end{tabular}

Tab 0.05- $(38)=2.042, *=$ Significance, NS= Not Significance

Table 1 shows that the mean and standard deviation of Soccer Players and B.P.Ed. students on speed has been found $7.18 \pm 6.51$ and $.36 \pm .31$, the mean and standard deviation of Soccer Players and B.P.Ed. students on Agility has been found $10.26 \pm 9.66$ and $.31 \pm .22$, the mean and standard deviation of Soccer Players and B.P.Ed. on Explosive Leg Strength has been found $2.49 \pm 2.30$ and $.07 \pm .08$, respectively. The ' $t$ ' value of Speed is (4.47), the ' $t$ ' value of Agility is (4.61), the ' $t$ ' value of Explosive Leg Strength is (4.75), are found to be significant at .05 level of confidence (df 28).

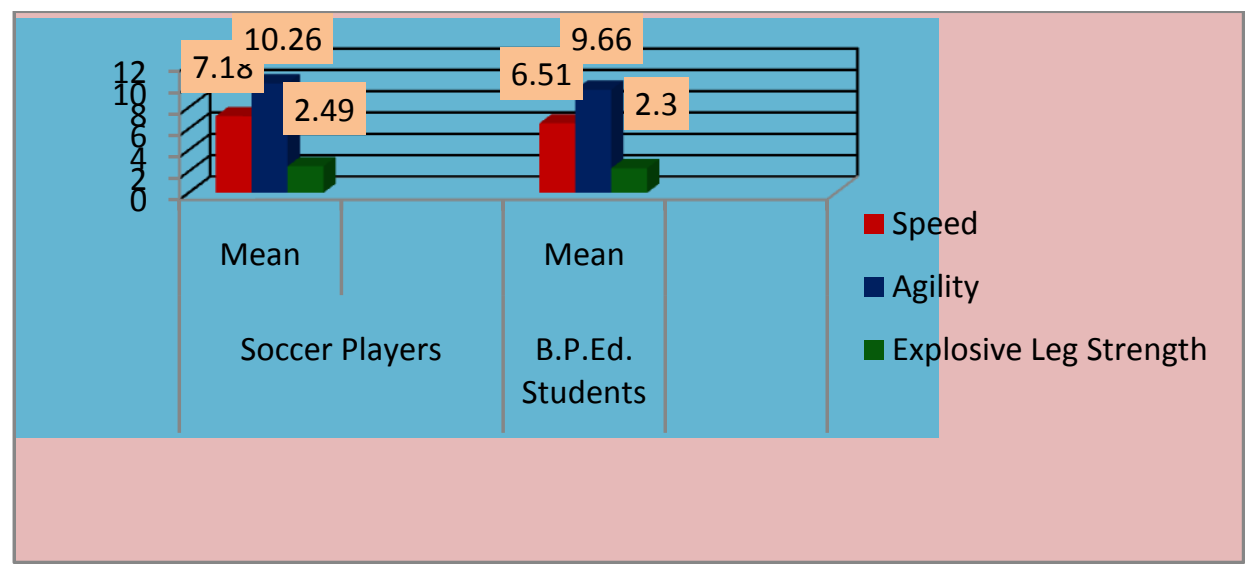

Fig. 1 Mean Difference of Speed, Agility And Explosive Leg Strength between Soccer Players and B.P.Ed. Students.

\section{Discussion And Finding}

The analysis of the data revealed that all the selected motor fitness components namely speed, agility and explosive leg strength differed significantly at 0.05 level of confidence when Soccer Players and B.P.Ed. students were compared.The result of the present study revealed that significance differences were found on speed, agility between Soccer Players and B.P.Ed. students. In case this two variables B.P.Ed. students better than soccer players because B.P.Ed. Students are involve various physical fitness training maximum time in their training schedule, their training schedule prepare to 10 months, otherwise soccer players also involve physical fitness training in few days.

It also found that there was a significant difference in Explosive Leg Strength of Soccer Players and B.P.Ed. students. In case of explosive leg strength soccer players better than B.P.Ed. students. Soccer players are mainly doing the different types of shooting, drive, kick etc. they are busy various types of jumping skill such as heading, back volley, bicycle volley etc. So case of explosive leg strength soccer players differs from B.P.Ed. students.

\section{Conclusion}

On the basis of result obtained in the present study following conclusion could be drawn:

The B.P.Ed. students are significantly better than Soccer Players in Speed and Agility, but Soccer Players better than B.P.Ed. Students in Explosive Leg Strength. 


\section{Journals And Periodicals}

\section{Refferences}

[1]. Micheal E. Crawford and Ron Mendell, Therapeutic Recreation and Adapted Physical Activities for Mentally Retarded Individual. N.J.: Prentice Hall Inc.,1987

[2]. P. C. Corbin, A Textbook of Motor Development $2^{\text {nd }}$ Ed. (Dubuque, IA: Wm. C. Brown, 1980), p.28.

[3]. Larry G. Shaver, Essentials of Exercise Physiology (Delhi; Surjeet Publications, 1981) p.106.

[4]. Bhatia Vinay "Comparative Study of Physical Fitness between Sub-Junior and Junior Athletes", Indian Journal of Movement Education and Exercises Sciences (IJMEES), Bi-annual Refereed Journal Vol. II No. 2 July - December 2012 http://www.google.co.in

[5]. Dr Bhowmik. S. "Comparision of Physical Fitness Between American and Bengal School Boys", Unmesh" may 2005 vol 1, No : 1(P.G.G.I.P.E, Banipur)

[6]. Warren K. Johnson, E. R. Buskirk, Science and Medicine of Exercise and Sports (London: Harper and Raw, Yoga Physical Education Bombay, The YogaInstitute 1971).

[7]. Hoff and Jan, "Training and Testing Physical capacities for elite Soccer Players" journal of sports sciences, 23:6, (June 2005): 573 582 cited at http://www.iegnta connect.com / content / tandf /risp.

\section{Books:}

[8]. Clarke David H, Clarke H. Harrison, "Research Processes in Physical Education", Second Edition, Englewod Cliffs, New Jerscy 07632 Prentice Hall INC., 1970.

[9]. Clarke H. Harrison, Clarke David H, "Application of Measurement to Physical Education", Sixth Edition, Englewod Cliffs, New Jerscy 07632 Prentice Hall INC., 1963.

[10]. Kansal Devinder K, “Text Book of Applied Measurement, Evaluation \& Sports Selection”, New Delhi: DVS Publications, 1996.

\section{Internet Sources}

[11]. http://www.unm.edu/ lkravitz/Article\%20folder/history.html

[12]. http://kireetjoshiarchives.com/teachers_training/mystery_excellence/physical-education-ancient-india.php\# 